\title{
OS HETERÔNIMOS (POSSÍVEIS) EM MACHADO DE ASSIS
}

\author{
Robson Coelho
}

RESUMO: "This paper when considering Man's manifestations, Author and Narrator, in Machado de Assis, intends to verify them as ethical-aesthetic components. Such components, articulate, expose the base of the production literary machadiana and they reveal an implicit intention of, more than to write to the people, to inform them about the real world in that live."

PALAVRAS-CHAVE: autor, narrador, homem, sociedade, literatura.

Machado é um escritor em quemo aspecto fortemente retórico do estilo, longe de lesar reforça a energia mimética da linguagem, reforça o seu poder de fingir (ficção) efetivamente a variedade concreta da vida.

José Guilherme Merquior

Brincava a criança, com um carro de bois;

Sentiu-se brincando e disse: eu sou dois! Fernando Pessoa

Este trabalho procurará fazer uma análise de Machado de Assis, estabelecendo um processo, diria, circular (para os gregos, o círculo representava a figura perfeita, por não ter dobras, curvas, fim nem começo - a aliança usada entre os que se casam tem este sentido figurado de "unir por aquilo que é perfeito"), que tem seu início/fim no Homem e finda/inicia-se no Narrador. Para tanto, levará em conta as influências sócio-culturais como um dos elementos decisivos para o conjunto de obras produzido

Robson Coelho é professor da Universidade de Brasília. 
- qualquer produção, ainda mais se possui um teor fortemente literário, é uma expressão representativa da(s) ideologia(s) de seu produtor. A verdade é que há infindáveis "Machados", mortos-vivos e eternos, assumindo sua forma e espaço nas ruas, nas alcovas, nas repartições, templos. Contemplando a todos eles, do fundo dos seus sete palmos de terra fertilizada por vermes alimentados de carne pútrida e sabedoria imaculada, Brás Cubas - defunto, antes; autor, depois - anuncia ironicamente pela voz quincasborbiana (voz de um de seus heterônimos): "Ao vencedor as batatas!"

Para tanto, apesar dos seus Brás, Bentinhos, Capitus (Capitolina, aliás, seria um nome que, para o escritor Josué Montello representaria “capitular", ou seja, para ele, Machado teria deixado marcado no nome da personagem o ato de não resistir à traição), Quincas, o escritor será analisado em três de suas manifestações, havendo, claro, umas tantas outras a ser consideradas e redescobertas. Apesar, ou ao lado, dessas tantas outras, aquelas três estariam agindo, sob a análise de uma óptica realista, de maneira independente. Todavia, em uma visão mais ampla - nem tão científica, nem tão romântica -, e sobretudo mais representativa da posição do autor no panorama nacional e mesmo mundial da época, elas seriam como elementos que se complementam, formando "partes de um todo", sempre em conflituosa harmonia. Esse conflito, em sua base literária, seguiria o princípio do que foi chamado de princípio de indeterminação ${ }^{l}$.

$\mathrm{Na}$ argumentação a seguir apresentada, aquelas manifestações, por estarem interligadas e serem fidedignas da personalidade machadiana, serão consideradas como que sendo "heterônimos" do senhor Joaquim Maria Machado de Assis - pessoa com uma história de vida única que se estruturava como conseqüência, diária, de um conjunto de fatores sociais, políticos, religiosos, artísticos etc. Esse conjunto de vida, como qualquer outro, caracterizou-se pelo lugar onde ele nasceu e cresceu, pela família, pelas pessoas que o educaram, pelos lugares onde viveu, por suas funções e cargos profissionais, pelas pessoas que o admiraram sem restrições e por aquelas que $o$ invejaram (não houve uma que conseguisse ficar indiferente a sua presença ou a suas análises); é ainda caracterizado por suas dúvidas, amores, tédios; suas idéias, personagens e a presença, desejável entre temida, da morte; é, sobretudo e fundamentalmente, caracterizado por duas presenças absolutas: a da solidão e a de sua amada esposa Carolina. Seriam três essas manifestações aqui consideradas, ou, seus heterônimos:

- O Homem.

- O Autor.

- O Narrador.

1“Com o discurso literário, então, a coisa se complica um pouco mais. Porque ele é um universo mágico. A propriedade mais característica de um universo mágico é que nele tudo se organiza, ou se desorganiza, a partir de um princípio que vou chamar de princípio de indeterminação: num universo mágico, como o do texto de literatura, tudo pode acontecer porque qualquer coisa pode dar origem a qualquer outra coisa. (...) tudo é previsível e, paradoxalmente, tudo é imprevisível.” (LOPES, 1993, p. 12). 


\section{O HOMEM}

Machado de Assis, na visão acadêmica entre ainda espantada de alguns críticos, foi considerado como um bruxo irônico, homem da escuridão tortuosa do pensamento, taxado de o "bruxo do Cosme Velho", "homem subterrâneo", "monstro de lucidez" (MOISÉS, 1985, p. 91). Machado das idéias de abismo era também o Machadinho, no dizer de seus colegas de jornal, que o consideravam um ser afável, avesso a brigas gratuitas e ideologicamente correto, claro, à maneira machadiana de ser. Foi, pois, desses intelectuais que, à primeira vista, poderiam bem estar compondo uma típica imagem de um ser a-social e politicamente discreto, quase passivo, dada sua opção pelo "distanciamento" de atividades públicas, sobretudo as partidárias. Mas sempre, mais para algumas pessoas; menos, para outras, levando em conta sua particularíssima visão de mundo e de ser humano, esteve atento às mudanças sociais e aos "perigos", nos mais variados níveis, que rondavam o país e sua população.

Como colaborador em alguns dos órgãos da imprensa carioca do período, o que se percebe é uma pessoa preocupada com os caminhos das letras nacionais, quando, por exemplo, exige uma série de providências (como articulista no jornal $A$ Marmota) a fim de defender o teatro brasileiro, em suas manifestações de assuntos e temas e mesmo no tipo das encenações desenvolvidas, que o escritor via como exageradamente dependente da cultura francesa de então, tida como aquela que devia ser "copiada". Nessa linha, é valiosa a tese de Gilberto Freyre (1977, p. 427) quando, ao tratar desse "estrangeirismo" do Brasil, avalia que "(...)o brasileiro do litoral ou da cidade viveu, durante a primeira metade do século XIX - na verdade durante o século todo - sob a obsessão dos "olhos estrangeiros" (...)que eram os olhos europeus. Eram os olhos do Ocidente. Do ocidente burguês, industrial, carbonífero (...)".

Amadurece o Homem, amadurece a obra. Daquela primeira fase romântica na superfície mas realista na essência, em que Machado desenha histórias e personagens ainda afetados pela linha alencariana de construção narrativa até o escritor realista procurando mostrar o ser humano real, o que se tem, sem dúvidas, é um crescimento pessoal que resvala pelo social, moral, psicológico e, entre anglicamente irôni$\mathrm{ca}^{2}$ e tropicalmente humorística, com uma visão de vida sarcástica. Amadurecido, enfim, e resultando em alterações na relação estabelecida com as pessoas, com os personagens criados, com os leitores, relação que não é independente das alterações pelas quais o Brasil passava quanto à produção das atividades culturais de maneira geral que, basicamente como a literatura, usavam a escrita como meio eficaz para sua apresentação às pessoas. Nessa linha, Lajolo (1993) faz uma análise muito interessante sobre a questão da leitura, de um escritor realista e já renomado, no Brasil de finais do Século XIX.

Machado de Assis é essencialmente um Homem Realista (em essência, repi-

2“(...) Natural que ao começo se enxergasse no humor de Machado de Assis o eco de suas leituras inglesas (...). Por muito tempo se considerou o humor como um atributo inerente à raça saxônica, se não mais restritamente à britânica." (PACHECO, s/d, p.34). 
to, pois com olhos e alma voltados à humanidade como causa/fato histórico e não como mera massa composta por ideais e visões tecnificistas) à medida em que percebe e, de certa forma, reforça os valores que norteiam os grupos e comunidades sociais em torno a si. Sendo realista a sua maneira, questiona os dogmas positivistas e deterministas buscando uma integração entre as normas científicas e os acontecimentos sociais. Busca resgatar conceitos perdidos no azáfama de aceitar tudo cientificamente provado como sendo "certo ou errado". Considera que dentro das normas há o que pode ser avaliado como possível ou não, o que, de certa forma, aproxima-o das proposições de Taine (e não que Machado se sentisse na obrigação de ser "determinista") quando este avalia que

"If you believe that in human nature the essential element is reason, you will take reason as your hero and you will decipt generosity and virtue. (...) Your opinion about nature will dictate your opinion about beauty; your idea about real man will form your idea of the ideal man (...)"(BECKER, 1967, p. 110).

É Homem Realista em uma sociedade com articulações entre seus grupos (dominantes e dominados) já muito particulares e marcados pela própria construção da nação brasileira que tem um percurso do descobrimento à colonização marcado por questões basicamente mercantis e de enriquecimento das várias metrópoles européias, muito além das da coroa portuguesa. Esse percurso, em finais do Segundo Reinado e inícios das primeiras manifestações republicanas, estrutura-se em um cenário tipicamente brasileiro e, portanto, contraditório: crescem nas cidades do "Brasil litorâneo", de maneira confusa, expressões capitalistas de produção de bens culturais ao mesmo tempo em que nos "outros Brasis" - esses e aquele tão bem retratados por Euclides da Cunha - ainda imperam relações quase que medievais. Fazendo um estudo do Brasil desta época, Bosi (BOSI, 1982) avalia que de um lado, havia as benesses dos mecenas e suas fortunas; de outro, impostos de governos arcaicos sobre traduções e reivindicações de direitos autorais.

Em uma longa citação, é ainda Bosi (Idem, p. 12) quem considera que "nos primeiros anos do século XX, continuando uma conquista das duas décadas anteriores, a dignidade do ofício de escrever estava razoavelmente reconhecida. (...)O mercado literário havia ganho uma dimensão, tanto no livro, como nos jornais e revistas, que indicava profundas alterações na vida econômica, social e cultural do país. O trabalho livre, a diversificação econômica, a divisão das atividades, a urbanização, a ampliação da rede escolar média e superior, o crescimento do aparelho burocrático estatal, o crescimento de frações de classes médias, a consolidação de alguns jornais e o aumento de sua tiragem e circulação, entre outros fatores, indicava que a divisão de classes na sociedade brasileira entrava em processo de atualização capitalista, e isso favorecia a circulação dos bens culturais, diversificando sua produção e apropriação."

Machado de Assis foi um leitor voraz de tudo quanto se produzia em sua época, antes de ser um escritor que a representasse com tanta objetividade e tão refi- 
nado trabalho literário. Ele se impôs essa condição básica: ler de tudo e todos para poder ter uma visão realmente representativa da época e do meio em que estava vivendo; suas mazelas, desejos e valores. Leve-se em conta que o motivo principal desta "imposição" dava-se, sobretudo, pela questão de Machado, por muito tempo, ter morado nos arrabaldes da cidade do Rio de Janeiro, onde era muito deficiente a circulação e o contato com livros e outras manifestações culturais, tão comuns nos "centros" das cidades. Essas dificuldades, aliás, fizeram com que ele sempre buscasse ser, ainda mais e em nome de sua percepção de mundo, um homem em sintonia com o que era escrito e publicado no país. Os trabalhos por ele realizados enquanto jornalista, crítico de arte e escritor exigirá essa atenção. E menos não poderia ser; jamais seria, com Machado. É o próprio escritor que, embasado em seu "projeto consciente", avalia que se deve exigir do escritor, antes de tudo, é certo sentimento íntimo, que o torne homem do seu tempo e do seu país" (Idem, p. 17).

Ainda quanto à presença e disseminação pelas mais variadas camadas sociais do "objeto livro" e, consequentemente, do ato de ler e, por ele, estar (re)descobrindo o mundo, agora dentro de um contexto histórico fundado pelas teorias de Darwin, Comte, Spencer, Taine, Zola, Flaubert, Eça, Shopenhauer, entre outros, Machado avalia extensamente, em alguns de seus vários "textos esparsos", escritos pelo final da década dos cinqüenta, a presença do livro em contraposição ao que se poderia chamar de "advento real" do jornal.

O ilustre morador do Cosme Velho analisa a relação, já na sua visão crítica e um tanto cética quanto, parece, confortadora, todavia para ele nunca bem resolvida, entre produção escrita por meio de livro e por meio de jornal, admitindo, segundo Bosi (Idem, p. 20)

"o aniquilamento do livro, porque o jornal "é a verdadeira forma da república do pensamento. É a locomotiva intelectual em viagem para mundos desconhecidos, é a literatura comum, universal, altamente democrática, reproduzida todos os dias, levando em si a frescura das idéias e o fogo das convicções. O jornal apareceu trazendo em si o gérmen de uma revolução. Essa revolução não é só social, é econômica, porque é um movimento da humanidade abalando todas as suas eminências, a reação do espírito humano sobre as fórmulas existentes do mundo literário, do mundo econômico e do mundo social."

O escritor procurava escrever. Escrevendo, via no jornal a possibilidade de um contato com um maior número de pessoas e de forma mais rápida, ou seja, à medida que mais pessoas escrevem e mais pessoas lêem, a tendência "natural" seria a de um ambiente mais democrático no convívio social e isto impediria que injustiças acontecessem tão impunemente. Escrevendo, sentia no livro e na construção de "seus mundos e pessoas" a possibilidade de discutir, apresentando com a imparcialidade e análise psico-filosófica necessárias, os porquês dos atos e vontades das pessoas sempre querendo mais e, por isso, nunca satisfeitas. Ainda mais em se tratando da personalidade do brasileiro, tão misturada quanto influenciada pelas mais variadas raízes. Nessa linha de influência racial é Prado Jr. (1989, p.343) quem avalia que 
“(...) em alguns setores a escravidão foi mais fecunda. Destaquemos a "figura boa da ama negra" - a expressão é de Gilberto Freyre - que cerca o berço da criança brasileira de uma atmosfera de bondade ternura que não é fator de menor importância nesta florescência de sentimentalismo, tão característico da índole brasileira, e que se de um lado amolece o indivíduo e o desampara nos embates da vida (...) doutro contribui para quebrar a rudeza e brutalidade próprias de uma sociedade nascente.”

Machado exercia muito bem os dois papéis, claro, que infinitamente melhor o de escritor de textos literários em prosa (seus poemas e textos dramáticos nada mais têm que uma razoável qualidade literária), o que, aliado a sua personalidade de ser solitário e atento o colocou como sendo um "desajustado" frente aos outros escritores da época. Segundo Lúcia M. Pereira (In A. BOSI et alli, op. cit., p. 31)

"o desajustamento entre Machado e os escritores do seu tempo provém, afinal, tanto da sua intrínseca superioridade como do fato de haver ele seguido o ritmo da vida política e social das classes dominantes, enquanto os outros se atrasavam perdidos na busca do elemento típico. O seu comedimento, o seu urbanismo, a sua urbanidade, o seu gosto pelos meios-tons, o seu estilo e as suas atitudes sempre compostos, as suas reservas, a sua falta de frescura, o seu ceticismo (por vezes aparente, mas sempre pessimista) a até o seu anglicismo eram qualidades que teve ou quis ter a gente mais representativa do Brasil de Pedro II."

É preciso avaliar a fala acima, todavia, com um certo cuidado, já que no entender da autora (Idem, p. 32), não haveria maiores conflitos entre produtor (homem) e produto (texto), ou seja, sua análise teria sentido apenas parcialmente, na medida em que a experiência do homem Machado de Assis estaria presente nas personagens criadas pelo autor Machado de Assis, mas não só; também nelas estariam presentes a ideologia e análise de situações características a determinada faixa social, na época e naquele meio. Aliás, esse "posicionamento" machadiano, que a mim parece ser o mais representativo de sua personalidade de homem e escritor, vai de encontro frontal à idéia propugnada por Gustave Flaubert, já que o autor francês considerava fundamental um total afastamento e imparcialidade do autor realista frente a sua obra e nela, a ação dos personagens.

Machado estava inserido no seu momento e meio social como quem, tímida mas atentamente, percebe a evolução (ou seria involução?) da pessoa brasileira em um país soltando-se de suas amarras coloniais e buscando novos caminhos frente à insurgência das novas relações internacionais - de fato, o fenômeno da "globalização" vem sendo construído desde finais do século passado e não deste, como crêem os mais desavisados. Schwarz (Idem, p. 42) considera, em uma análise muito perspicaz, que a obra machadiana, todavia busque afirmar a santidade da ordem e da família, não tem nessas manifestações a representação de sua melhor parte e que haveria como que uma autorização fornecida pelo conformismo nas coisas essenciais, para tornar possível uma investigação das razões, por vezes insólitas, que, na verdade, embasavam a vida familiar. Daí, segundo o analista, "a liberdade na 'transcrição dos costumes', a 
disposição de ver muito e complexamente, de que vão resultar os assuntos novos e notáveis".

Em nome dessa opção de uma vida em sociedade, escrevendo sobre ela e, de uma certa forma, sobre si mesmo enquanto integrante (ou querendo integrar-se para provar sua capacidade) de um grupo social que, por fim, estabelecia as normas burguesas de conduta, Machado de Assis, conscientemente e não, ocupou posições "flutuantes". Essas posições assumidas surgem como conseqüência do quadro sócio-político mundial gerando um novo contexto nacional denominado por alguns autores de "liberalismo caboclo", resultado da articulação entre a Europa burguesa, culta, industrial, urbana e anti-escravagista e um Brasil urbanizando-se mas ainda rural, assumindo novas relações interpessoais mas ainda de base patriarcalista, conservador e ainda preso às últimas amarras do trabalho escravo. Liberalmente conservador, Machado "vivia" naqueles dois mundos, mas assumia mais como seu o último, pois seu espírito liberal era caracterizado pelo respeito à tradição da família e das normas de boa conduta social (Idem, p. 36).

O Homem Machado de Assis, tal qual alguns de seus "heterônimos" mais famosos, como Quincas Borba (o homem e o cachorro), Brás Cubas, D. Casmurro parece que optou por deixar-se mesmo levar-se por aquele (e seria este um outro de seus heterônimos?) misterioso hipopótamo voador até o alto da montanha - retomando a Bíblia, citada no início do Memórias como elemento comparador da obra póstuma sendo escrita pelo defunto-autor, valeria a comparação com o diabo oferecendo ao Cristo sofredor e em dúvidas todos os reinos da terra? - para, do ponto máximo de visão, poder vislumbrar a evolução do tempo representada pelo passar dos séculos e poder perceber a síntese da própria existência humana ali, ante seus olhos cansados e questionadores (Idem, p. 44).

A Machado interessou mostrar a ação de uma sociedade desorientada pelos novos "apelos mundiais" cobrando das pessoas uma atitude essencialmente pragmática frente ao espetáculo da técnica e produtos manufaturados que então se apresentava. A nova revolução industrial mostrava a avidez de suas garras poderosas e atraentes cobrando de cada pessoa pressa e individualismo para adquirir seu espaço à sombra dos prédios das capitais sendo construídos num ritmo alucinante. Quanto a isso, é ler Walter Benjamin (1994) falando dos "palácios de ferro e vidro"; é lê-lo para escutar Baudelaire falando do nascimento das metrópoles européias como os novos centros de desenvolvimento e egoísmo.

Machado e seus "heterônimos", cada um com um tipo de percepção e reação, percebiam essa "evolução humana". Por vezes sofriam calados, casmurramente silenciosos; por vezes, atiravam-se ao frenesi do dia a dia, capitolinamente audazes; por vezes davam e retiravam, brascubasmente finitos-eternos. Para o autor interessava, na análise de Bosi (1982, p. 47),

"o espetáculo e não o cenário. Este foi o espaço das condições particulares em que o homem agiu. Centrado na questão do poder, portanto, da ação humana e das relações de produção na história, soube intuir e propor o nacional para além do localismo cultural e das formas particulares de or- 
ganização social. Daí a mobilidade do nacional. O nacional não como algum caráter acabado e fechado da sociedade brasileira, mas um movimento de mudança constante."

Mesmo a epilepsia daquele menininho negro e franzino do Morro dos Livramentos (na verdade, ela mais se manifestou na fase adulta do escritor), considerada antigamente como um tipo de "patologia mental" e que por isso, na análise de alguns estudiosos, teria tido uma grande influência na composição da obra machadiana, pode ser considerada como um elemento negativo ou dificultador para a criação do autor e a ascensão do homem frente a uma sociedade burguesa, ainda exageradamente europeizada por questões de raça e estirpe social. Epilépticos o foram também Dostoiévisk e Flaubert e não há, em quaisquer das obras dos três, elementos para provar, embora a doença possa provocar algumas alterações de personalidade, tons de desvario ou de qualquer outra manifestação "mais irregular" que não fossem construídas com o intuito de, antes de chocar a boa classe social querendo ler historietas românticas, pôr a nu a realidade do ser humano - criação irregular é o próprio ser humano, na visão de Shopenhauer, que não se satisfaz nunca com o que consegue ter.

O homem Machado de Assis, frente aos grandes assuntos de sua época, ainda, como a escravidão, o movimento abolicionista e a própria abolição, tende a assumir, ou a reafirmar, uma posição que desde moço norteia suas idéias e visão de mundo: denuncia, fortemente mas com discrição; mesmo seu entusiasmo é de um tipo silencioso e controlado, todavia sempre presente. comportou-se como sempre fizera desde a mocidade: da denúncia ao entusiasmo. Bosi (Idem, p. 49) afirma que

“(...)Para Machado a escravidão era uma situação social e econômica que transcendia o moralismo e as 'normas éticas' para situar-se no âmbito das relações de produção e na posse dos meios de produção. Na sociedade escravocrata o escravo não é propriamente mão-de-obra mas ferramenta."

Machado ocupa o centro da questão cultural brasileira porque produziu uma obra ousada buscando a novidade da estrutura narrativa e da trama entre seus personagens-pessoas. Esta opção, para alguns estudiosos, poderia ser chamado de sua utopia (que para Machado [Idem, p. 59] consiste no prazer do texto, na delícia que rege o conhecimento do mundo por via da fruição como fala desinteressada mas capaz de produzir o prazer). Dessa ousadia e inovação o fruto maior foi, sem dúvidas, sua capacidade de recriar o mundo para as pessoas frente a sua própria concepção de um mundo marcado por relações interpessoais materialistas e imediatas. O "lucro fácil" das personagens machadianas é-nos repassado mediante um fabuloso trabalho artístico de domínio da língua e de suas linguagens de sinais, metáforas, sensações. Ler Machado é ler, literariamente, a construção aliada à desconstrução da natureza humana. Há algumas falhas, claro, mas são tantas as qualidades...

Machado, homem de/em dois mundos, soube trabalhar a integração das culturas, dos valores no que eles possuem de comum e típico. Muito mais que isso, soube "não se perder" nessa mistura tão ao gosto de tantos escritores mais desavisados de que o mundo, que é um, é também necessariamente composto por partes diferentes. 
De um ângulo, um homem centrado nos trópicos e seus desajustes culturais; de outro, um homem compenetrado e irônico, descrevendo a natureza humana como se tivesse sido criação sua. Ainda

"de outro ângulo, digamos que ao materialismo vulgar dos contemporâneos de vanguarda, tão sob medida para o nosso dilema racial e a vastidão do trópico, Machado contrapunha o racionalismo setecentista, de corte voltariano, com seu interesse humorístico pela diversidade e irracionalidade

\section{O AUTOR}

das instituições" (SCHWARZ, 1991, p. 124).

O autor Machado de Assis, "continuação sempre em fase da acabamento" do homem, preocupou-se em narrar histórias verossímeis à medida em que a verossimilhança, mais que uma exigência estilística daqueles tempos determinados por questões anti-românticas e, portanto, anti-idealizantes e anti-subjetivas, mostrava-se como o caminho "mais curto" a ser seguido por quem desejasse chegar ao âmago de uma descrição real da sociedade. Nessa linha, pois, histórica e social, Machado construiu o que se denominou como quadros de sua galeria de tramas narrativas e personagens, sendo, esta construção, uma excelente fonte de informações para, até, a análise da história social da leitura, no Brasil, dos cinqüenta anos finais do século XIX. Essa análise, se aplica mais ao Machado autor de Contos, sobretudo, no entender de Lajolo (op. cit.), pode ser estendida, ampliada, ao Machado também romancista.

Machado de Assis usava de vários recursos para a construção de "suas vidas e seres sociais". Usava-os à exaustão de sua criatividade ousada e inovadora, o que, em tese, pode parecer uma redundância, afinal, quem cria, inova, mas era "a forma" como o autor criava que o colocava em posição de destaque frente aos escritores de sua época. Segundo Candido (In SCHWARZ, 1991, p. 27), Machado "usava recursos arcaizantes para obter efeitos modernos", como na utilização de elementos românticos (os sonhos de casar, de ter uma família, de ser fiel etc.) servindo de base a uma conseqüência realista (a traição, o interesse, o conforto material etc.) ou nas, por vezes, longas descrições "emperrando" o andamento da história, em que o autor vai aprofundando e revelando as características psicológicas do ser humano, em suas personagens.

Desde o começo de suas manifestações como escritor, Machado de Assis já arruma, ou des-arruma, suas histórias na intenção de misturar e fundir leitores em personagens. Na verdade, a maior parte delas já como que nascia com três personagens (aqui a manifestação de sua heteronímia) constantes: o leitor, o narrador e o próprio autor. Nessa fusão, o leitor adentra a matéria narrada como sendo um personagem que, sem ser avisado, vê-se "puxado" para dentro de uma vida que poderia muito bem ser extensão da sua própria - aqui a fabulosa riqueza autoral de Machado: ele inventa vidas reais. Seria, no entender de alguns estudiosos, o caminho percorrido do romance-texto para o romance-vida.

Enquanto escritor-homem (VIANA, 1984, p. 24) o autor busca avaliar a força da 
metalinguagem como expressão da linguagem buscando ser informação e desvelamento do íntimo recluso das pessoas em suas posições sociais impostas por necessidades e desejos culturais. Essa força metalingüística apresenta-se nas "variações estilísticas" criadas e é na ironia que se revela com mais intensidade e precisão: Machado é um "irônico" por natureza e opção. É o autor, ainda e sempre, preocupado com o ato de leitura como hábito assumido para entender, e mais criticamente, o meio e o momento que se vive. A questão da leitura, para Machado, era indissociável da macro-questão cultural e tanto, que sempre buscou torná-la agradavelmente provocadora, também, com o intuito de que o leitor, lendo-o, buscasse ler mais qualquer autor. Segundo Lajolo (op. cit., p. 80)

"a constância da metalinguagem através da qual Machado, a pretexto de
seus leitores, mas sobretudo para eles, tematiza o ato de leitura em curso
inscreve no texto uma espécie de pedagogia da leitura, que não destoa do
contexto brasileiro das últimas décadas do século passado, quando o ne-
cessário fortalecimento do sistema cultural era bandeira assumida por to-
dos os intelectuais." A autora ainda avalia que

“(...)Se a hipótese é plausível, ela sugere que os distintos tratamentos que Machado, pela boca de sues narradores, dispensa a seus leitores, articulam-se bem com o longo processo sofrido pela obra literária em seu percurso de objeto concebido como destinado à fruição gratuita até seu estatuto de mercadoria (...).

"E entre ambos, iluminando um pelo outro, o texto literário de Machado que, historicamente inscrito nessa transição, parece textualizar a questão, encenando-a literariamente pela via da metalinguagem que assim desvela não só o projeto de uma escrita literária, mas também seu reverso e sua historicidade, qual seja, a necessária educação de leitores que dêem conta de tal escrita." (Idem, p. 85)

Em toda sua assumida excentricidade, o texto machadiano apresentou-se como "desajustado" refletindo, no mais, o "desajuste" da sociedade de então, promovendo, graças à imposição incontrolável dos acontecimentos históricos, uma reorganização de seus valores e ideais. Essa excentricidade é resultado do trabalho literário construído, basicamente, na sátira, paródia, humor e ironia aliados a uma qualidade absurda de "retratar" a natureza humana em seus descaminhos morais, seus desvãos sentimentais, suas patologias psicológicas entendidas como "normais" em uma sociedade venerando o sucesso e o destaque pessoais a qualquer preço.

O romance tipicamente romântico, fundado na concepção e idealização alencariana de Brasil, de mundo - em uma análise mais restrita, do que seria a figura do "herói brasileiro" em comparação ao herói medieval -, buscou representar uma sociedade monoliticamente conservadora. Na linha de produzir uma obra, pontualmente, "excêntrica" (fora do centro/eixo normal de uma produção literária), Machado de Assis tende a construir um romance pseudo-romântico ou mesmo anti-romântico, substituindo aquela "idealização" por uma observação objetiva/crítica da socie- 
dade brasileira - seu dia a dia, costumes, valores, normas de conduta -, abrindo, com esta atitude, uma riquíssima frente de pesquisa ideológica, muito mais que meramente literária, descompromissada com os valores burgueses de tais e quais grupos sejam. Afirma Bosi (1982, p. 33) que "também em muitas crônicas da década de 1870, Machado está liberto de conservadorismo, solto a rir, ironizar, distanciado dos "compromissos ideológicos", submetendo os valores sociais à corrosão, semelhante àquela que será sua marca depois da década seguinte."

Todavia não foi fácil, muito pelo contrário, para Machado perceber a "congenialidade das formas artísticas produzidas por Alencar e a sociedade patriarcal/escravocrata" (Idem, p. 35). Era possível ser liberal e, de certa forma, conservador. Era possível pois, comungar com as idéias modernistas pregadas pelos intelectuais europeus e conviver com a escravidão sendo um mera questão de fundo cultural. Era possível "aclimatar aqui certo modelo do romance burguês europeu e reproduzilo com a respectiva cor local e fórmula adaptadas ao meio." Não foi, enfim, por acaso, que Machado de Assis buscou outros eixos de produção, outras linhas de expressão, indo buscá-los em outras fontes que, por demais disponíveis a quem as procurasse, poucos (em sua época, só ele) descobririam e poderiam usufruir de sua capacidade de "gerar" boa literatura.

Mesmo na sua natural e constante neurose para estar re-criando a forma e o conteúdo do texto a ser produzido, a base da narrativa machadiana - as relações das personagens entre si e com o meio que as continha e a análise psico-realista de seus caracteres - estruturava-se seguindo as normas de um modelo sociocultural fundado em relações essencialmente patriarcais e, como bem assinala Roberto Schwarz, em seus estudos, tendo como condicionantes básicas o favor e o interesse. Mesmo não sendo a única, e nem a mais forte, essa "tendência ideológica" na obra de Machado de Assis finda por criar um romance até ousado na forma mas contido nos temas e limitado a um tipo de passividade frente às imposições da vida. Contudo, segundo Bosi (Idem, p. 37), "Machado conhecia os limites do entrecho da narrativa romântica de aventura e procurou transpô-los para realizar outro projeto literário." quem avalia:

Quanto a esse projeto literário, é o próprio Machado, em texto de 1872,

“(...) "Não há dívida que uma literatura, sobretudo uma literatura nascente, deve principalmente alimentar-se dos assuntos que lhe oferece a sua região; mas não estabeleçamos doutrinas tão absolutas que a empobreçam. O que se deve exigir do escritor antes de tudo, é certo sentimento íntimo, que o torne homem do seu tempo e do seu país, ainda quando trate de assuntos remotos no tempo e espaço" (Idem, p. 38).

Pode-se considerar comum na estrutura do romance romântico, notadamente o de aventura, o caráter psicológico das personagens como um "dado invariável" e, por este prisma, sua irrealidade. Essa invariabilidade, fator presente nas obras machadianas de primeira fase, ainda marcadas pela forte presença de um "realismo romântico" foi, digamos, rompida - para possibilitar uma ampliação de elementos na ação/reação das personagens. Este rompimento deu-se com a apresentação de um 
enredo centrado, antes de uma análise do individualismo como norma de convivência com as outras pessoas (personagens), na manifestação dos grupos sociais estabelecendo/impondo suas relações determinadas pela idéia do geral subjugando o particular, do impessoal sobre o pessoal. Principalmente nessa nova disposição dos elementos da narrativa havia um potencial estético para um rompimento radical das normas e convenções daquele gênero aventuresco favorecendo e encaminhando a produção machadiana de segunda fase (Idem, p. 40).

Os romances da chamada fase adulta de Machado de Assis tendem a não apresentar conclusão nenhuma - não há neles o que se possa chamar propriamente de final esperado, tão ao gosto romântico -, seguindo, aliás, o ritmo dos acontecimentos diários da vida: há uma sucessão, a cada instante, de fatos originando outros fatos. Resta, pois, compreender essa opção pelo "fim sem final" como uma saída em busca da análise filosófica, da concepção metafísica apresentando-se em resposta ao caos $\mathrm{real} /$ concreto da vida e nela, suas necessidades e limitações. Seria, esse tipo de fugabusca social, um dos elementos imanentes na obra machadiana que Candido (1970) avalia como uma das características mais marcantes de sua vasta produção em prosa.

Se Machado de Assis busca representar em suas obras a realidade de uma sociedade caracterizada por desejos, receios e dúvidas; se busca tratar de personagens verossímeis como se fossem retratos fidedignos de um momento histórico caótico, dadas "as revoluções" nos mais variados níveis - do religioso ao da vestimenta, do artístico ao das regras de etiqueta - e se a vida em sociedade é, em essência, indeterminada em seus grupos de interesse, variável em seus acontecimentos, cheias de altos e baixos (em acompanhamento aos "'índices econômicos, por exemplo), claro está que as personagens machadianas deveriam, até por condição de existência, representar esta inexorável dança real e objetiva.

Nessa linha, as posições das personagens são continuamente móveis, alternando-se do desejo compreensível para o incompreensível; da atitude perdoável para a imperdoável; da vontade razoável para a loucura; da riqueza entre amigos para a pobreza solitária; do status quo em destaque para o anonimato execrado. Tudo isso em um "vai-e-vem" sempre possível, pois a vida é assim mesmo e quem poderá dizer o contrário? reversíveis, continuamente deslocadas, do alto para baixo e vice-versa; da periferia para o centro e vice-versa; da razão para a loucura e vice-versa; da pobreza para a fortuna e vice-versa; do anonimato ao prestígio e vice-versa. Nenhuma posição será validada como definitiva, com estabilidade garantida. Por serem essas posições sempre articuladas com o poder e a ideologia, é absolutamente compreensível entendê-las como posições móveis e fluidas (BOSI et alli, 1982, p. 44).

Em um ensaio avaliando a inovação literária na produção de Machado de Assis, Antônio Houaiss considera o trabalho com a metalinguagem como sendo o denominador comum a vários dos elementos que representariam aquela inovação. Argumenta o estudioso que

"em primeiro lugar, caracteriza-se essa inovação por seu aspecto metalingüístico - isto é, pela quase obsessiva postura mental de Machado em não apenas usar da língua, mas, ao usar dela, indagar-se de si para sisimulacradamente, pois de fato o que faz é dialogar com o próprio leitor- 
com velhos recursos verbais ad hoc sobre os velhos recursos verbais de que os seus personagens estão fazendo uso como que inerte: dessa combinação inusitada de dois 'velhos', nasce-lhe sempre o 'novo'." (BOSI et alli, 1982, p. 57)

Bosi, avaliando a metalinguagem inserida na concepção do "livro-vida (ou vida-livro)" para Machado de Assis, busca ainda em Houaiss, que agora lança um questionamento, para abrir ainda mais trilhas até a cidade machadiana, sempre indescoberta, onde, quiçá, descansam seus deuses, pajés e gurus:

"Essa postura metalingüística - que poderia ter sido escamoteada ou subtraída, se a ficção machadiana se processasse através de outro tipo de relação 'autor-leitor' específico - traduz tão-somente uma necessidade de inovação (carga de informação) ou reflete, antes, a manifestação de uma cosmovisão que atribuía à linguagem e seus usos o valor de uma das formas mais explícitas de ser homem e, concomitantemente, uma das formas mais poderosas de esconder, subtrair, deformar, iludir a humanidade e, assim, obter desumanamente de outrem algo para proveito próprio (não dele, Machado de Assis., mas dos personagens entre si)?" (BOSI et alli, 1982, p. 58).

Além da dimensão estética, em que o trabalho com a metalinguagem é o grande elemento inovador, a linguagem literária machadiana compõe-se por meio de uma outra, fruto do conhecimento como aspecto de pesquisas e leituras do próprio autor. O caráter pragmático dessa opção artística é representado pela composição de locais, ações e personagens que, articulados, propõem o desvelamento de um modus vivendi “tão conhecido" dos leitores que, alçados à esfera das personagens, como que atendem aos apelos do autor-narrador e findam por participar, de,fato, da narrativa. Assim, permitindo um grande prazer estético pelo ato próprio da leitura, ao mesmo tempo em que expressa a miséria humana, essa linguagem tem sua grande força no que se poderia chamar de contradição assumida. Essa linguagem, "engendra o prazer na realização estética mediante o humor e o riso como dimensões existenciais que se chocam e conflitam com os antagonismos que dividem os homens e as formas de dominação que os desumanizam e os oprimem" (Idem, p. 59). O conjunto da produção machadiana foi articulado, sobretudo, em bases daquilo que seria, em uma análise mais superficial, simplesmente paradoxal; todavia primou pelo uso do "contraditório" como forma de pôr a nu os interesses da burguesia travestidos em atitudes ortodoxas de um convívio social fundado no respeito e na sinceridade.

O senso da "segunda intenção", do "propósito velado" em Machado de Assis é o que confere a sua obra a condição paradoxal (na verdade, condição da própria vida) de trabalhar o verdadeiro, o real, o objetivo com pinceladas de humor, ironia e sarcasmo. Buscando sempre através do dito o que não poderia ou deveria ser dito, o autor exagera no detalhamento dos efeitos conseguidos, das imagens construídas, das revelações íntimas da natureza humana feitas. Enquanto autor-narrador, Machado edifica em si, mais ainda naquele último, o ponto fulcral dos acontecimentos de sua prosa; atitude que, segundo Schwarz (1991, p. 18) tende a fazer com que a composição do 
conjunto pouco apareça. a qual, todavia, existe e deixa entrever os grandes contornos de uma estrutura social, desde que o leitor "atento" consiga manter uma certa distância "segura" e não seja tragado pelo canto de sereia do autor-narrador (as palavras entre aspas são minhas).

A posição ocupada pelo Brasil, nação de $3^{\mathrm{a}}$ ordem (ou $4^{\mathrm{a}}$ ?) no panorama mundial da época, sempre foi um elemento de preocupação para o autor que buscou, mostrando os conflitos típicos de uma sociedade rural e escravocrata, provar que os "novos tempos" também haviam chegado às terras brasileiras. Para tanto, procurou usar de fórmulas narrativas que, não deixando de atender às exigências culturais e do ainda frágil mercado editorial no país, pudessem ampliar a concepção e o entendimento da pessoa em um meio e momento determinados por novos conceitos filosóficos, científicos, artísticos e técnicos, todos eles interligados por uma visão realista de mundo.

Machado de Assis foi universalista por necessidade e opção. Sua visão de mundo, sua visão da pessoa nesse mundo primava por uma descrição e discussão que levassem em conta o conceito de nacional brasileiro integrado ao conjunto sóciohistórico das outras nações, interessando para ele mais que a idéia do "mundo do Brasil", a idéia do "Brasil no mundo". Creio ser válida essa análise que se amplia ao todo da obra machadiana, confirmada por Schwarz, mesmo quando ele a delimita ao Memórias Póstumas de Brás Cubas:

"Acertos, impasses, estreitezas, ridículos, dos predecessores e dos contemporâneos, nada se perdeu, tudo se recompôs e transfigurou em elemen-

to de verdade. Por outro lado, longe de representar um confinamento, a formalização das relações de classe locais fornece a base verossímil ao universalismo caricato das Memórias, um dos aspectos da sua universalidade efetiva" (Idem, p. 225).

\section{O NARRADOR}

A figura do narrador, em Machado de Assis, sempre foi um elemento de destaque na construção de suas histórias e na composição dos perfis psicológicos de seus personagens. Aliás, mais que "um elemento", o narrador foi O ELEMENTO em que sua prosa se estruturou. Vem confirmar essa característica narrativa, o fato de, já em Contos Fluminenses, sua primeira obra em volume, de 1870, o leitor "ser chamado" inúmeras vezes a participar dos acontecimentos, a saber de suas possíveis causas e conseqüências na vida dos personagens, a avaliá-los sob sua própria óptica (sendo, assim, mais um personagem). Desde então, na análise de Lajolo (1993, p. 78), “o leitor comparece não poucas vezes, tratado sempre com deferência e educação, na boca do que se poderia chamar de um narrador cordial."

Já na "fase adulta" de Machado, caracterizada pela famosa trilogia dos seus mais fabulosos romances, a saber, Dom Casmurro, Quincas Borba e Memórias póstumas de Brás Cubas, sobretudo neste último, o narrador aparece agora de maneira mais obsessiva e, até, inconveniente, como que em posição de afronta. Há uma assu- 
mida persistência na "conversa com o leitor" o que, no entender de Schwarz, funcionaria como um elemento técnico e conferiria às Memórias seu ritmo próprio. Nessa intenção o narrador, a todo momento, desobrigado de explicações e cuidados com suas "atitudes", ainda segundo o autor,

"invade a cena e "perturba" o curso do romance. Essas intromissões, que alguma regra sempre infringem, são o recurso machadiano mais saliente e famoso. A crítica as tratou como traço psicológico do autor, deficiência narrativa, superioridade de espírito, empréstimo inglês, metalinguagem, nada disso estando errado." (SCHWARZ, 1991, p.17).

Machado de Assis vai demonstrando, sobretudo com o Memórias, o fím de um ciclo da literatura nacional à medida que trabalhava literariamente a idéia geral desenhando a sociedade, o romance, a fatalidade, o clímax, a ação, o personagem. A figura do narrador realista/naturalista, em que esses dois aspectos confluíam tão harmoniosamente - sem que um restringisse a manifestação do outro -, apresenta-se desvinculada de qualquer regra imposta pelas várias intelligentsias européias de então, exigindo ou uma visão patológico-naturalista ou uma visão positivo-realista do mundo e das pessoas. Aliás, quando era preciso, Machado sabia articular, como ninguém, essas duas correntes. No seu heterônimo de narrador, soube olhar mais além e ver o "naturalismo" sem a capa pesada de um incontível desvio de ordem sexual, mas como uma outra expressão típica dos novos tempos. Pode-se dizer que seguia a linha de Leopoldo Alas quando argumenta sobre "What Naturalism is not":

"Naturalism is not a collection of rules for writing novels, as many unwary people have thought. Although it denies the chimerical abstractions of a kind of aesthetic psychology which speaks of myths of inspiration, afflatus, genius, rapture, artistic disorder and other sometimes immoral inventions; although it conceds much to the forces of work, good sense, reflection, and study, it is far from denying to the foolish the right of turning themselves into artists or entering its temple." (In BECKER, 1967, p. 269)

Machado de Assis entrelaça em suas obras, por meio da atuação do narrador, situações que vão do mais tépido humorismo ao sarcasmo mais agressivo, fruto de uma análise da natureza humana - seus sintomas e conflitos - percorrendo planos de ocorrências dos mais variados - dos simples até os mais complexos. Esse trabalho narrativo, sobremaneira apresentado no Memórias, é uma condição-base de seus romances demonstrando, clara e ousadamente, a liberdade no trato da matéria literária e seus elementos de composição como a metáfora, os pleonasmos, ritmo narrativo, descrição sinestésica, quebra das normas gramaticais estabelecidas etc.

O narrador machadiano extrapola sua função textual endógena e, livre das amarras do texto narrativo formal, passou a atuar além da matéria narrada, estabelecendo uma relação de proximidade entre a linguagem do texto apresentado e a própria linguagem da sociedade - o texto "fala" da e com a sociedade como um órgão representativo de suas relações, dentre elas, as formas de comunicação. Segundo Bosi (1982, p 40), essa posição inovadora do narrador coloca a sociedade não mais atrás 
de si, mas na frente, à medida em que acentua a noção do real sem que a realidade se limitasse à dimensão positiva do apenas aquilo que é visivel é normal.

A mudança do foco narrativo apresentado pelo texto de Machado de Assis serve como plano para que o "social", representado pela linguagem do narrador, manifestese de maneira mais adequada ao próprio entendimento do leitor; serve para que ele (o leitor) não avalie essa manifestação como algo distante de si, como fatos tirados de um mundo de faz-de-conta. Essa nova posição do narrador, diferente do narrador romântico típico - impassível e distante - coloca-o no alto dos acontecimentos, "vendo" a amplitude possível das vontades veladas, dos segredos guardados, das palavras pensadas e não ditas, dos olhares lançados a outros olhares, proibidos. O narrador trata de situações que são resultado, ainda, do ambiente colonial que por séculos caracterizou a organização social do país. Nessa linha da formação de uma cultura intelectual brasileira, sempre muito presa ao seu passado histórico, aplica-se a argumentação de Prado Jr.:

“(...)Ao influxo do sangue indígena como fator de indolência, ainda há que acrescentar esta causa geral que é o sistema econômico da colônia, tão acanhado de oportunidades e de perspectivas tão mesquinhas. Não seria um tal ambiente propício a estimular as energias e as atividades dos indivíduos, uma escola muito favorável de trabalho.

"De tudo isto resultará para a colônia, em conjunto, um tom geral de inércia. Paira na atmosfera em que a população colonial se move, ou antes "descansa", um vírus generalizado de preguiça, de moleza que a todos, com raras exceções, atinge" (PRADO Jr., 1989, p. 365).

O que se percebe das leituras dos textos de Machado de Assis é um narrador assim construído: narrador-personagem da história; narrador convidando (por vezes obrigando) o leitor a assumir esta posição: a de personagem-leitor. Percebe-se um deslocamento operado pela mudança de posição do narrador, que passa a proferir um discurso sociocultural em um tom de voz diferente do que era utilizado até então. O resultado é que

"esse narrador novo tem (...) trânsito livre entre os membros das classes dominantes, é reconhecido como um deles e entre eles circula com suas armas carregadas de humor e ironia. É um narrador à vontade em sua classe ou fração de classe, com a segurança de sua integração, do seu conhecimento dela" (BOSI et alli, 1982, p. 63).

As "vozes" do narrador, nem sempre concordantes, estabelecem entre si um tipo de harmonia, não havendo a sobreposição de nenhuma delas sobre as outras. $\mathrm{O}$ narrador irônico discursa quando a intenção é demonstrar a fragilidade da natureza humana submissa aos interesses materiais; o sentimental dá vistas ao lirismo fundado na simplicidade e ingenuidade dessa mesma natureza; o bem-humorado invade o texto quando se trata de "ridicularizar" com graça e tepidez aquilo que, de fato, é engraçado. E as outras "vozes" tantas... prontas a serem manifestadas no exato instante de sua necessidade; com que classe, com que qualidade literária, com que senso de crítica e análise elas aparecem... 
Schwarz (1991) defende uma tese interessante considerando que sem estar prejudicando os limites de atuação do narrador, sua volubilidade e abusos cometidos ao longo da narrativa retêm uma característica específica (no entender de Antonio Candido, avalia o estudioso, seria uma "redução estrutural") de um movimento que a circunstância histórica impunha aos grupos dominantes. O texto machadiano, enfim, entre volúvel e sintomático, por meio da figura do narrador, nunca estabelece uma verdade inquestionável, deixando claro (ou mais ou menos, pois é a sociedade quem esconde as informações) que tudo é fundado em uma relação causa/conseqüência em que o "jogo dos interesses" é o que conta e tem sentido. A verdade, por exemplo, apresentada nas partes de sua integridade, é variável e se manifesta ao sabor dos interesses e necessidades de cada personagem.

A questão de que tudo giraria em torno do poder é a idéia básica veiculada pelo narrador machadiano. Tudo, enfim, seria uma questão de ter, ou não, poder. De conseguir manipulá-lo e colocá-lo à mercê dos interesses pessoais ou dos grupos dominantes. A função do narrador, no mais, seria acompanhar, atentamente, os movimentos da sociedade - dos grupos sociais - na busca de sua diária acomodação frente às exigências de uma vida confortável, segura e sem grandes esforços para conseguir esses "bens"; seria a de demonstrar um certo relaxamento quanto às posturas, desde o colonialismo impostas por uma visão de vida patriarcal, assumidas frente aos relacionamentos sociais. Gilberto Freyre, analisando a figura do "herói" nos romances nacionais, percebeu bem essa questão de "desdivinização" dos personagens (em Machado, das pessoas-personagens):

"O período pós-patriarcal do romance nacional reflete, desde o início, certa descontração no sistema rígido de moral, de conduta, de costumes, com uma tentativa de fuga aos condicionamentos patriarcais. O herói continua moço. No entanto, as heroínas adolescentes entram numa curva decrescente. Já aparecem sem aquele extremo juvenil em idade, característico da heroína patriarcal. (...) O vilão do período pós-patriarcal continua seguindo o herói em muitos pontos. Há menor contraste entre a figura do herói e a do vilão." (FREYRE, 1979, p. 95).

Machado de Assis foi, heteronicamente, vários sendo um só e seria impossível não pensar, nessa linha de análise, na heteronímia (travestida de tais e quais nomines sejam) de todos quantos foram escritores, enfim, artistas, ou mesmo agiotas, covardes, larápios, traidores etc. etc. Mais impossível ainda é não pensar nos famosíssimos heterônimos do fabuloso poeta português Fernando Pessoa e render-se à inevitável pergunta: "Mas qual é a novidade, então?"

A novidade está em como "os Machados" conviveram dentro e fora do Machado (ser único, mas múltiplo) pois, mais do que na intenção do escritor em criá-los - a qual Fernando Pessoa teve ao criar seus "Pessoas", conferindo-lhes local, data de nascimento e como que uma vida própria -, ela se estabelece na convivência pacífica, construtiva e crítica entre eles. Os heterônimos de Machado tiveram vida dependente um do outro, com a particularidade machadiana de representarem, cada um deles, um outro olhar para lugares diferentes de onde os outros olhavam, ou seria uma mera 
questão de "amplitude" de olhar; quem sabe? Em Machado de Assis, cada um de seus Machados foi imprevisto mas tinha um lugar e momento de atuação-acontecimento. Cada um responsabilizou-se por compor a unidade do Homem José Maria Machado de Assis para que, dessa unidade, fosse extraída uma compreensão ampla de seu momento histórico.

No "bruxo de Cosme Velho", paradoxalmente, criador e destruidor de normas literárias, - bruxo franciscano de Assis, batizado também Joaquim Maria (nome da mãe daquele também paradoxal homem-não homem que veio à terra "trazer a espada, não a paz" ${ }^{3}$ ) - os heterônimos, na verdade, não existem. Eis a novidade. Na verdade, não sendo fantasias ou delírios ou vontades ou jogos de cena, são a parte posta à marca feroz dos dias de um escritor que "brincou seriamente" com a natureza humana no desvelamento de seus mais recônditos segredos. Eis a novidade. Além de tornar-se ser literário (de asas, dono de todos os deuses), Machado de Assis, a sua maneira, nunca deixou de ser assim: pessoa perecível de carne e osso. E sofreu por isso; e viveu só; e desenhou, em si, a linha diária da paradoxal tortura prazerosa de estar vivo. Eis a novidade.

Machado dá adeus a Machado:

"Foi-se a melhor parte de minha vida, e aqui estou só no mundo. Note que a solidão não me é enfadonha, antes me é grata, porque é um modo de viver com ela, ouvi-la, assistir aos mil cuidados que essa companheira de 35 anos de casados tinha comigo; mas (...) a vigília aumenta a falta da pessoa amada.(...) e eu contava morrer antes dela, o que seria um grande favor, primeiro, porque não acharia ninguém que melhor me ajudasse a morrer; segundo, porque ela deixa alguns parentes que a consolariam das saudades, e eu não tenho nenhum.(...) Aqui me fico, por ora na mesma casa, no mesmo aposento, com os mesmos adornos seus. Tudo me lembra a minha meiga Carolina. Como estou à beira do eterno aposento, não gastarei muito tempo em recordá-la. Irei vê-la, ela me esperará."

Brás Cubas dá adeus a Machado:

"Não tive filhos. Não transmiti a nenhuma criatura o legado de nossa miséria."

??????????!!?????...

Concluindo (como se fosse possível o uso dessa forma gerundiva com qualquer um dos heterônimos vasculhando a natureza humana), mas, enfim, tentando concluir as considerações levantadas e com o ousado desejo de estar abrindo mais uma porta para que elas, machadianamente, passem deixando suas marcas indeléveis, esta foi apenas mais uma análise. Tem a qualidade, modesta, de buscar ser coerente com os Machados de Assis apresentados, pois "a coerência é em parte descoberta pelos processos analíticos, mas em parte inventada pelo crítico, ao lograr, com base na intuição e na investigação, um traçado explicativo. Um, não $o$ traçado, pois poder

${ }^{3}$ Cf. Bíblia Sagrada, Mt., 10, 34-36. 
haver vários, se a obra é rica" (CANDIDO, 1981, p. 38).

\section{BIBLIOGRAFIA}

BECKER, George J. (edictor). Documents of modern literary realism. Second printing. Princeton, New Jersey, Princeton University Press, 1967.

BENJAMIN, Walter. Charles Baudelaire - um lírico no auge do capitalismo / Obras escolhidas III. Traduzido por José Carlos Martins Barbosa e Hemerson Alves Baptista. 3 ed. São Paulo, Brasiliense, 1994.

BOSI, Alfredo et alli. Machado de Assis: antologia e estudos. São Paulo, Ática, 1982.

CANDIDO, Antonio. Formação da literatura brasileira: momentos decisivos. v. 1.6 ed. Belo Horizonte, Itatiaia, 1981.

. Vários escritos. São Paulo, Duas cidades, 1970.

FREYRE, Gilberto. Sobrados e Mucambos. Rio de Janeiro, José Olympio, 1977. . Heróis e vilões no romance brasileiro. São Paulo, Cultrix / EDUSP, 1979.

LAJOLO, Marisa. Do mundo da leitura para a leitura do mundo. São Paulo, Ática, 1993.

LOPES, Edward. A palavra e os dias. São Paulo, Ed. UNESP, Ed. UNICAMP, 1993. MOISÉS, Massaud. História da literatura brasileira. vol.III. São Paulo, Cultrix, 1985.

PACHECO, João. O realismo. São Paulo, Cultrix, s/d.

PRADO Jr., Caio. Formação do Brasil contemporâneo. 21 ed. São Paulo, Brasiliense, 1989.

SCHWARZ, Roberto. Um mestre na periferia do capitalismo - Machado de Assis. 2 ed. São Paulo, Duas cidades, 1991.

VIANA Filho, Luís. A vida de Machado de Assis. Porto, Lello \& Irmão - Editores, 1984. 